\title{
Modeling of time dependent thermal process in sliding electrical microcontact
}

\author{
Alexander Ilyin, Igor Plokhov, Igor Savraev, Oksana Kozyreva \\ Pskov State University, Electromechanical Faculty, \\ Department of Electric Drive and Automation Systems. \\ Address: Lenina 8, Pskov, 180000, Russia
}

\begin{abstract}
Temperature has great influence on mechanical, electrical and chemical processes that occur in transition layer of sliding contact. The aim of the research is creating a three-dimensional finite-element model for calculating time dependent thermal process in sliding electrical microcontact.

The article starts with the description of the contact element representing a discrete microcontact and physics in it. Then the authors suggest use modern simulation software COMSOL Multyphisics for modeling.

The developed 3D-model uses modules of electric currents, heat transfer in solids, and electromagnetic heat source for computing. For each module the assumptions, the initial and boundary conditions are made.

The outcomes of modeling are the transient processes of average overheat in the elements of contact-details surface layers. The transient processes depend on geometric size of the microcontact (size of contact element, height of surface elements, thickness of oxide films, and overlap), contact-details physical properties (density, electrical conductance, thermal conductivity, and heat capacity), external influences (electrical current and friction heat), and temperatures of the neighbor elements.
\end{abstract}

The results of the research will be used in the numerical simulation model of sliding electrical contact.

Keywords: sliding electrical contact, simulation model, time dependent thermal process.

\section{INTRODUCTION}

Electrical contacts can be found at a variety of practical application. Good performance of the brush slip rings has particular importance for large-power electro-generators. The research is concerned with the modeling and the simulation of processes in the sliding electrical contact. Basic concepts of the processes in sliding electrical contacts and algorithms of the simulation model are given in $[1,2]$ that was based on researches in [3-13].

There are different modeling methods. Computer simulation is an important feature in engineering systems or any system that involves many processes. It can be used to estimate the performance of systems too complex for analytical solution. The scale of events being simulated by computer simulations has far exceeded anything possible using traditional mathematical modeling.

Computer simulation is the imitation of the operation of a real-world process or system over time using a single computer or a network of computers. The act of simulating requires that a model representing the key characteristics and behaviors of the system be developed. The model represents the system itself, whereas the simulation represents the operation of the system over time.
The developing simulation model of sliding electrical contact is:

- stochastic, as it uses random number generators to model random events;

- stencil code, because stores data in regular grids and require only next-neighbor access.

For some past time several algorithms of the simulation model were improved: microscale surfaces generation, computation of the contact surfaces overlapping, evaluation of the constriction resistance of the contact spots cluster, and other $[14,15]$. The physicochemical properties of the contact materials depend on temperature varying within wide range. Therefore thermal processes have significant influence on other physical processes: electrical, mechanical, and chemical. Thus we have to propose a new improved model for calculating time dependent thermal process in sliding electrical contact. In this work we will develop a computational model of heat conduction in a microcontact, run test computing experiments, and discuss how to use the results in the simulation model. 


\section{MATERIALS AND METHODS}

\section{Model scheme}

To solve transient heat conduction in the microcontact we designed the model of the contact element (Fig. 1). The contact element is composed of two interacting surface elements. Each surface element is a hemisphere of radius $d x / 2$ based on a $d x$ square face of a rectangular parallelepiped with the height $h-d x / 2$, where $d x$ is the size of the contact element and $h$ is the height of the surface element. The hemispheres overlap on the distance $\delta$ depending on heights of the surface elements and the applied load. In the overlapping volume is located a heat source $P_{f r}$ equal to the power of friction in the sliding contact. An electric current $I$ flows through the contact element. The hemisphere consists of two domains with different values of electric conductivity. In the domain $r \leq d x / 2-f$ the conductivity is equal to the contact material conductivity. In the domain $d x / 2-f<r \leq d x / 2$ the conductivity is equal to the material of oxide film. There $f$ is the thickness of the film. In figures and expressions we will use index $b r$ (brush) for one contact and index $r$ (rotor) for the other.

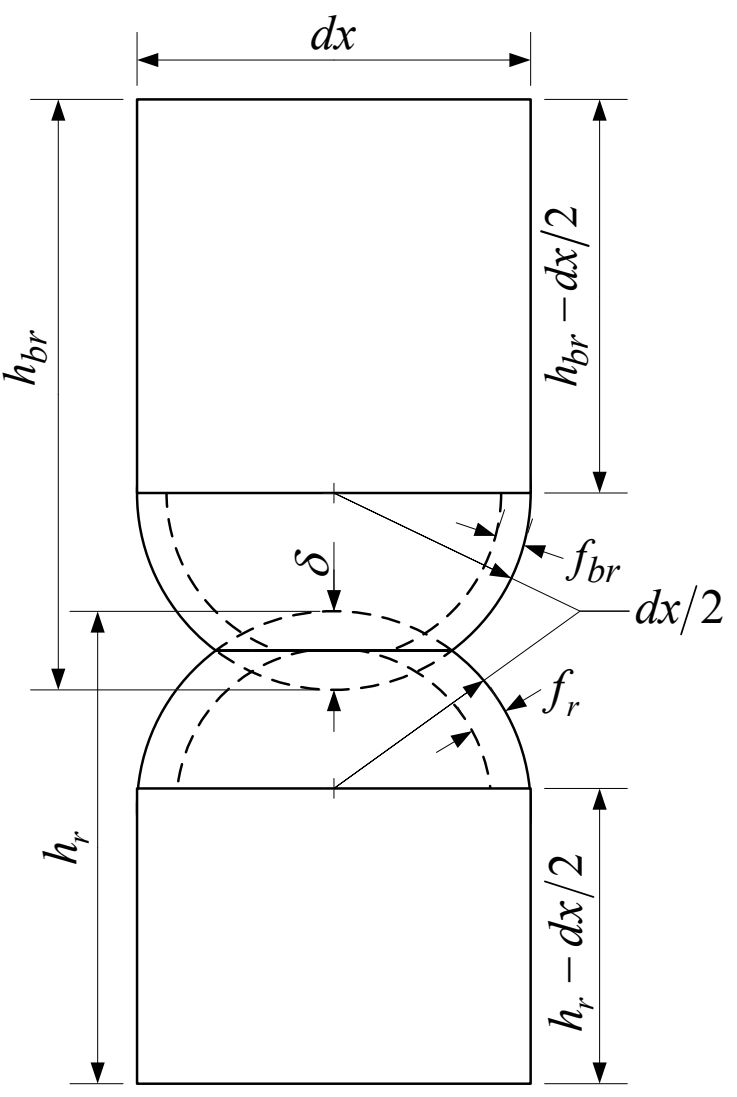

Fig. 1. Scheme of the contact element

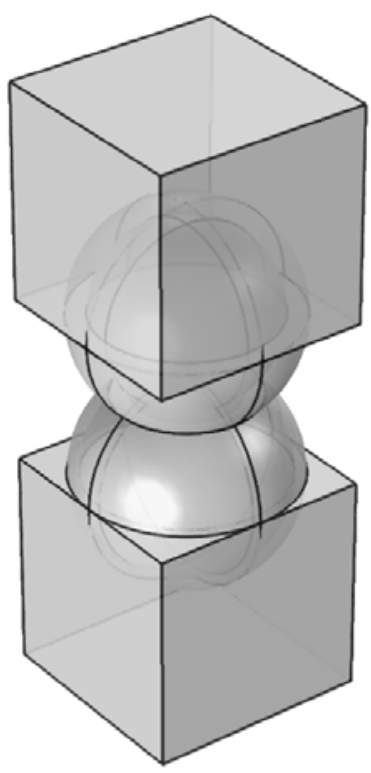

Fig. 2. Three-dimensional view of the contact element

It is necessary to determine: the time dependence of the average temperature of the surface elements, heat fluxes between the surface elements, heat fluxes to the neighbor surface elements, and heat fluxes to the contact bodies. View of the contact element in threedimensions is shown on Fig. 2.

Using the model of contact element we developed computational model in COMSOL Multiphysics (Fig. 3). The computational model includes the neighbor and body elements for each surface element. The model uses modules: Electric Currents, Heat Transfer in Solids, and Electromagnetic Heat Source.

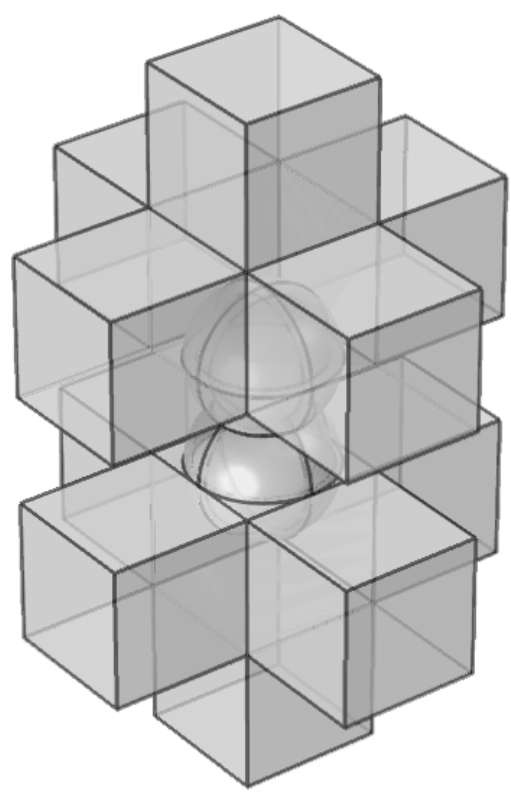

Fig. 3. COMSOL Multiphysics model 


\section{Initials and boundaries}

The model represents closed system and the external surfaces are thermally insulated from the environment.

The surface element of the brush has the initial overheat $\theta_{b r}$. We will use the term overheat for the difference between the temperature of an element and the environment temperature. The initial overheats of the four neighbor elements are $\theta_{b r 1}, \theta_{b r 2}, \theta_{b r 3}$, $\theta_{b r 4}$. The most top cubic element represents the body of the brash and has the initial overheat $\theta_{b r 0}$. For the rotor surface element the initial overheats in the same way are $\theta_{r}, \theta_{r 0}, \theta_{r 1}, \theta_{r 2}, \theta_{r 3}, \theta_{r 4}$.

In the overlapping domain of the rotor and brush hemispheres is situated the heat source with total power $P_{f r}$ that depends on friction ratio, sliding velocity, and applied load.

The physics Heat Transfer in Solids is applied to all of the model domains. The physics uses for calculation equation

$$
\rho C_{p} \frac{\partial T}{\partial t}+\rho C_{p} u \cdot \nabla T=\nabla \cdot(k \nabla T)+Q
$$

where $\rho$ is density, $C_{p}$ is heat capacity at constant pressure, and $k$ is thermal conductivity for an element material; $T$ is temperature field $(\mathrm{K}), u$ is velocity field $(\mathrm{m} / \mathrm{s}), Q$ is heat source $\left(\mathrm{W} / \mathrm{m}^{3}\right)[16]$.

The module Electric Currents uses physics Current Conservation for calculation of all domains with equations

$$
\begin{aligned}
& \nabla \cdot J=Q_{j}, \\
& J=\left(\sigma+\varepsilon_{0} \varepsilon_{r} \frac{\partial}{\partial t}\right) E+J_{e}, \\
& E=-\nabla V,
\end{aligned}
$$

where $\sigma$ is electrical conductivity of a material; $J$ is current density $\left(\mathrm{A} / \mathrm{m}^{2}\right), Q_{j}$ is boundary current source $\left(\mathrm{A} / \mathrm{m}^{3}\right), E$ is the electric field strength $(\mathrm{V} / \mathrm{m}), J_{e}$ is external current density $\left(\mathrm{A} / \mathrm{m}^{2}\right), V$ is the electric potential (V).

The initial electric potential value of the elements is $0 \mathrm{~V}$. The boundary electric potential of the most bottom side of the rotor body cubic element also is $0 \mathrm{~V}$. For the most top surface of the brush body cubic element is specified the normal current density $J$ defined as

$$
J=\frac{I}{d x^{2}} .
$$

All of the other external surfaces are electrically isolated from the environment.
The multiphysics module Electromagnetic Heat Source uses Joule heating as addition to $Q$ in the equation (1).

\section{Assumptions and properties of materials}

In this section we will describe assumptions made in the model that may affect on the accuracy of the model.

All of the neighbour elements have the same height as the brush surface element and the rotor surface element.

In reality the size of the brush and the rotor is about three orders more than the contact element size $d x$. Therefore the properties of materials for the cubic elements of the contact bodies are specified in ratio due to units

$$
\begin{gathered}
\rho^{\prime}=\rho\left[\frac{\mathrm{kg}}{\left(10^{-3} \mathrm{~m}\right)^{3}}\right]=10^{9} \rho\left[\frac{\mathrm{kg}}{\mathrm{m}^{3}}\right], \\
C_{p}^{\prime}=C_{p}\left[\frac{\mathrm{J}}{\mathrm{kg} \cdot \mathrm{K}}\right], \\
k^{\prime}=k\left[\frac{\mathrm{W}}{10^{-3} \mathrm{~m} \cdot \mathrm{K}}\right]=10^{3} \mathrm{k}\left[\frac{\mathrm{W}}{\mathrm{m} \cdot \mathrm{K}}\right], \\
\sigma^{\prime}=\sigma\left[\frac{\mathrm{S}}{10^{-3} \mathrm{~m}}\right]=10^{3} \sigma\left[\frac{\mathrm{S}}{\mathrm{m}}\right] .
\end{gathered}
$$

For the oxide films domains the electrical conductivity $\sigma$ is equal to zero, since the electrical conductivity of metal oxides is several orders less than for metals and it can be neglected.

\section{Experimental procedure}

For the test computational experiment the parameters provided in Table 1 are used.

TABLE 1.

PARAMETERS OF THE TEST EXPERIMENT

\begin{tabular}{ccc}
\hline$\#$ & Parameter & Value \\
\hline 1 & $d x$ & $8 \mu \mathrm{m}$ \\
\hline 2 & $h_{b r}$ & $11 \mu \mathrm{m}$ \\
\hline 3 & $h_{r}$ & $13 \mu \mathrm{m}$ \\
\hline 4 & $f_{b r}$ & $1.5 \mu \mathrm{m}$ \\
\hline 5 & $f_{r}$ & $0.8 \mu \mathrm{m}$ \\
\hline 6 & $\delta$ & $1.9 \mu \mathrm{m}$ \\
\hline 7 & $\rho_{b r}$ & $2500 \mathrm{~kg} / \mathrm{m}^{3}$ \\
\hline 8 & $C_{p b r}$ & $500 \mathrm{~J} /(\mathrm{kg} \cdot \mathrm{K})$ \\
\hline 9 & $k_{b r}$ & $40 \mathrm{~W} /(\mathrm{m} \cdot \mathrm{K})$ \\
\hline 10 & $\sigma_{b r}$ & $0.02 \mathrm{~S} / \mathrm{m}$ \\
\hline 11 & $\rho_{r}$ & $6500 \mathrm{~kg} / \mathrm{m}^{3}$ \\
\hline
\end{tabular}




\begin{tabular}{ccc}
\hline 12 & $C_{p r}$ & $250 \mathrm{~J} /(\mathrm{kg} \cdot \mathrm{K})$ \\
\hline 13 & $k_{r}$ & $75 \mathrm{~W} /(\mathrm{m} \cdot \mathrm{K})$ \\
\hline 14 & $\sigma_{r}$ & $33.333 \mathrm{~S} / \mathrm{m}$ \\
\hline 15 & $P_{f r}$ & $0.8 \mathrm{~mW}$ \\
\hline 16 & $I$ & $10 \mathrm{~mA}$ \\
\hline 17 & $\theta_{b r}$ & $0 \mathrm{~K}$ \\
\hline 18 & $\theta_{b r 0}$ & $1 \mathrm{~K}$ \\
\hline 19 & $\theta_{b r 1}$ & $0 \mathrm{~K}$ \\
\hline 20 & $\theta_{b r 2}$ & $0 \mathrm{~K}$ \\
\hline 21 & $\theta_{b r 3}$ & $3 \mathrm{~K}$ \\
\hline 22 & $\theta_{b r 4}$ & $0 \mathrm{~K}$ \\
\hline 17 & $\theta_{r}$ & $0 \mathrm{~K}$ \\
\hline 18 & $\theta_{r 0}$ & $-1 \mathrm{~K}$ \\
\hline 19 & $\theta_{r 1}$ & $0 \mathrm{~K}$ \\
\hline 20 & $\theta_{r 2}$ & $0 \mathrm{~K}$ \\
\hline 21 & $\theta_{r 3}$ & $0 \mathrm{~K}$ \\
\hline 22 & $\theta_{r 4}$ & $2 \mathrm{~K}$ \\
\hline
\end{tabular}

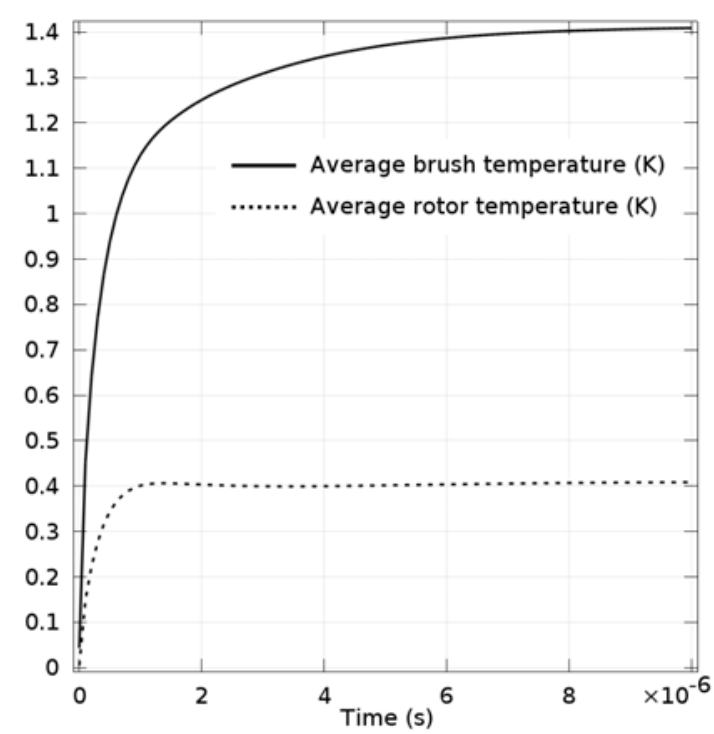

Fig. 5. The transient processes of the average overheats of the brush and the rotor elements

Fig. 5 shows the transient processes of the average

The modelling time $t$ is $10 \mu$ s with 100 steps each of the interval $d t=10^{-7} \mathrm{~s}$.

\section{RESULTS AND DISCUSSION}

The next figures show some results of the test experiment.

Fig. 4 presents the plot of the temperature distribution in the cut yz-plane for $\mathrm{x}$-coordinate is 0 on the last step of modeling $t=10 \mu \mathrm{s}$. As we can see the brush element has the temperature spot in the contact zone caused by the friction and Joule heating. The brush element overheat more than in the rotor element mostly due to lesser value of the thermal conductivity.

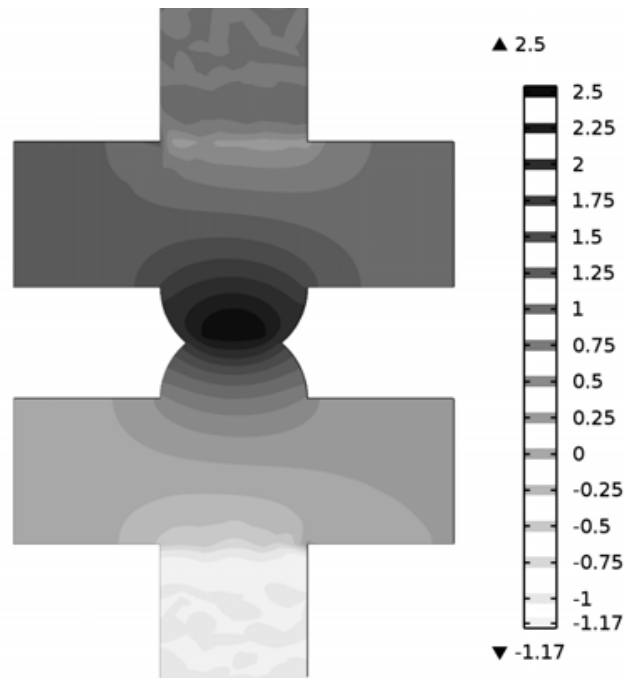

Fig. 4. Temperature distribution in yz-slice temperatures in the brush and rotor elements.

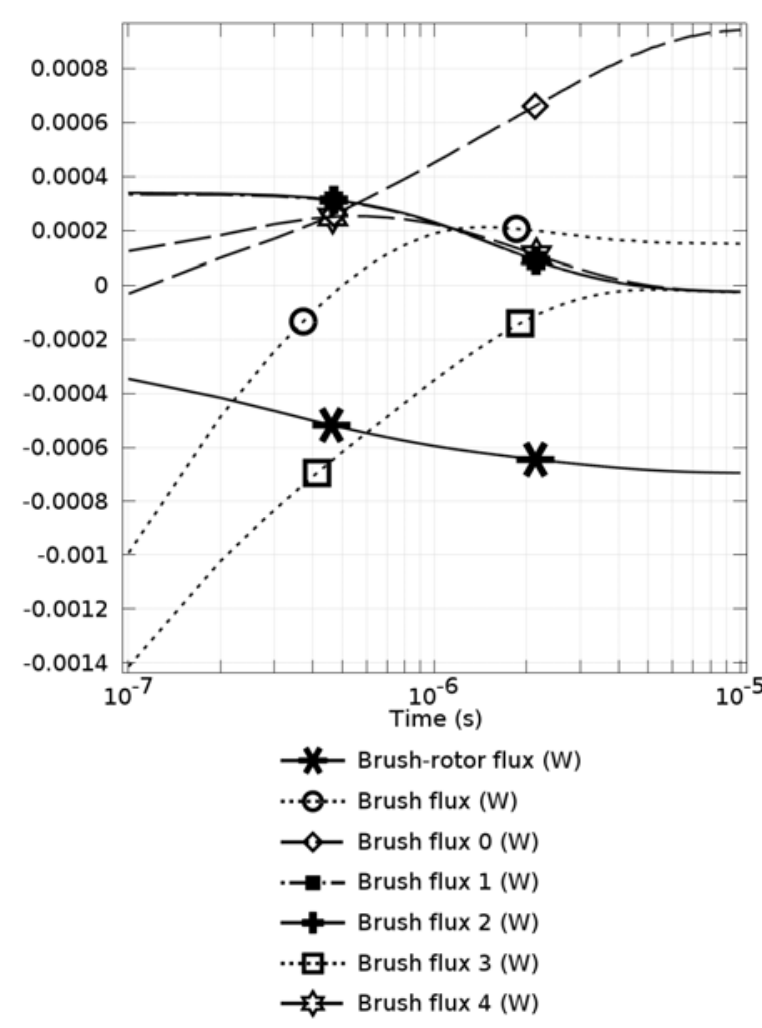

Fig. 6. The transient processes of the heat fluxes from the brush element to the neighbor elements

Fig. 6 illustrates the transient processes of the heat flux from the brush element to the neighbor elements. The brush flux (dotted line with circles) is the total flux from the brush element to the others. For better 
understanding the trends on Fig. 6 are shown on a logarithmic scale.

The results of this and other test experiments show that all of the transient processes may be approximated using second-order aperiodic elements.

\section{CONCLUSION}

This paper describes a three-dimensional computational model in COMOSL Multiphysics for calculating non-steady-state thermal processes in microcontact depending on the parameters of the contact element and the material properties of contacts. The outcomes of the model will be used in the simulation model of sliding electrical contact. Since the transient processes depend on many parameters (see Table 1) so we have to use experimental design theory for planning set of experiments.

\section{REFERENCES}

[1] И. В. Плохов, Комплексная диагностика и прогнозирование технического состояния узлов скользящего токосъёма турбогенераторов. Диссертация доктора технических наук. СПб: СПбГПУ, 2001.

[2] A. Ilyin, I. Plokhov, A. Isakov, "The simulation model of a sliding contact", ENVIRONMENT. TECHNOLOGY. RESOURCES: Proceedings of the 9th International Scientific and Practical Conference June 20-22, 2013. Volume II. Rezekne, Latvia, 2013, pp. 111-115.

[3] Р. Хольм, Электрические контакты. - М.: Иностранная литература, 1961.

[4] J. A. Greenwood, "Constriction resistance and the real area of contact", British Journal of appl. Physics. 1966. V.17. P.1621-1631
[5] Milenko Braunovic, Nikolai K. Myshkin, Valery V. Konchits. Electrical Contacts: Fundamentals, Applications and Technology. - CRC Press, 2010. - 672 p.

[6] В. В. Кончиц, $\quad$ В. В. Мешков, $\quad$ В. В. Мышкин, Триботехника электрических контактов. Минск: Наука и техника. 1986.

[7] А. В. Чичинадзе, Э. Д. Браун, Н. А. Буше и др. Основы трибологии (трение, износ, смазка): Учебник для технических вузов. 2-е изд. переработ. и доп. / Под общ. ред. А. В. Чичинадзе. - М.: Машиностроение, 2001. $664 \mathrm{c}$.

[8] Е. Федер, Фракталь: Пер. с англ. - М.: Мир, 1991. $254 \mathrm{c}$.

[9] Д. Б. Горохов, Контактное взаимодействие фрактальных шероховатых поверхностей деталей машин: Диссертация на соискание ученой степени кандидата технических наук. - Братск, 2005.

[10] К. Н. Войнов, В. А. Ходаковский, М. А. Шварц, «Математическое моделирование шероховатых поверхностей». Трение, износ, смазка. - 2009. - №41.

[11] В. Т. Омельченко В. Т, Теория процессов на контактах. Харьков: Вища школа. Изд-во при Харьк. ун-те, 1979. $128 \mathrm{c}$.

[12] Ф. Крейт, У. Блэк, Основы теплопередачи / Пер. с англ. М.: Мир. 1983.

[13] M. F. Gomez, Characterisation and modelling of brush contacts. - Humburg, 2005.

[14] А. В. Ильин, И. В. Плохов, О. И. Козырева, «Моделирование процессов электрофрикционного взаимодействия в узлах скользящего токосъема» Научнотехнический вестник Поволжья. - Казань: Научнотехнический вестник Поволжья, 2013. - №4. - С. 166-173. ISSN 2079-5920

[15] А. В. Ильин, И. В. Плохов, О. И. Козырева, «Моделирование микрорельефа поверхностей контактирующих деталей» Научно-технический вестник Поволжья. - Казань: Научно-технический вестник Поволжья, 2013. - №5. - C. 180-183. ISSN 2079-5920

[16] COMSOL Multiphysics Reference Manual, Version 4.4, November 2013. 